\title{
The Increase of Forage Productivity in Ex Coal Mining by Adding Fertilizer and Forage in East Kalimantan
}

\author{
Bariroh NR, Danial D, Gunawan SG \\ East Kalimantan Assesment Institute for Agricultural Technology \\ Jl. Pangeran Moh. Noor, Sempaja Sel, South Samarinda, Samarinda 75119, East Kalimantan \\ rizqibarir@yahoo.com
}

\begin{abstract}
East Kalimantan has many minerals that contribute $47.44 \%$ of province income. However, coal mining exploitation resulting poor quality of soil. One effort to recover this condition is by planting a right forage combined with fertilization. This study aimed to know forage productivity in ex coal mining with various fertilizations and forage combinations. This study was conducted in Petangis village, Paser district, East Kalimantan. Research method was Factorial Randomized Block Design. Factor 1 was forage combination, whereas (a) Brachiaria humidicola + centrosema pubescens and (b) Brachiaria humidicola + Stylosanthes guyanensis. Factor 2 was fertilization, whereas (a) control (b) manure (c) manure + lime (d) manure + urea (e) manure + lime + urea. All treatments were replicated three times. Area of each plot was $100 \mathrm{~m}^{2}$. Grass and legume were planted separately in the same plot. Parameters measured were forage height and forage production. Forage height was at the age of 30 days after planting in two seasons. Forage production was the total production of two forages in the same plot. Statistical analysis was performed using SAS portable 9.0. ANOVA was carried out to compare the difference of means. If there was a significant result, it was followed by Duncan test. The result shows that combination between Brachiaria humidicola + Centrosema pubescens and manure + urea was a significant result $(\mathrm{P}<0.01)$. The production of this treatment was 9.6 higher than other treatments
\end{abstract}

Key Words: Ex Coal Mining, Forage, Fertilization

\section{INTRODUCTION}

East Kalimantan area is rich in minerals, especially coal. Coal contributes $47.44 \%$ of the province total revenue (BPS 2013). Coal has been exploited on huge scale. This exploitation creates many serious problems, such as landscape changes which can disrupt natural balance. Open pit mining will bring up deep and wide holes. Dismantled land will be transferred to specific areas. It is often occured that a hill became a valley or vice versa. This causes changes in the stability of the environment and land prone to landslide (Yustika \& Talaohu 2006).

The opening land mines will result many problems in the future. East Kalimantan has a fairly extensive land mines, accounting for \pm 3.9 million ha. In 2009 reclamation land accounted for $\pm 2,309.52$ ha and revegetation area was 2,111.9 ha (BPMD 2012). This post exploitation area is projected to supply livestock feed requirement as many as 2,210.56 animal unit (AU), with assumption that $2 \mathrm{Ha}$ can accomodate $1 \mathrm{AU}$. This potency is quite large for agricultural activities although it requires large investment.

Furthermore the removal of topsoil causes an infertil soil for at least 10 years (Verhagen et al. 2001). The barren land leads to reduce soil biota which has a big role in nutrient cycle. Soil microflora responsible for most of decomposition process and nutrient flow, while soil microflora plays an important role in the formation of soil structure (Lavelle et al. 1997).

Usually there is a heavy metal accumulation in ex coal mining area. Vegetables cultivated in contaminated soil take up heavy metal in large amount that cause health risk 
to the human body. However, heavy metal accumulation depends on plant species (Rattan et al. 2005).

Selecting of forage combination and fertilizer use properly are expected to impove the condition of post mining land. Planting of forage not only improve ex coal mining fertility, but also capable to supply animal feed which in turn will increase ruminant production. This study aimed to know productivity of forage crops in ex coal mines with different fertilizer treatment and forage crops combinations.

\section{MATERIAL AND METHODS}

\section{Time and location}

This study was conducted in petangis village, Batu Engau Subdistrict, Paser District from January until December 2011. Materials used were seed of Brachiaria humidicola, Centrosema pubescens and Stylosanthes guyanensis, dung fertilizer, lime, urea and other agricultural inputs.

\section{Research design}

Research design used was factorial randomized complete block design with two factors and three replications. Treatments introduced were forage planting with various fertilizations.

Factor 1, Forage combination:

(1) B. humidicola and C. pubescens

(2) B. humidicola and S. guyanensis

Factor 2, Fertilization:

(1) Without fertilization

(2) Fertilization by using manure (20 ton/ha)

(3) Fertilization by using manure (20 ton/ha) and lime ( 2 ton/ha)

(4) Fertilization by using manure (20 ton/ha) and urea $(200 \mathrm{~kg} / \mathrm{ha})$

(5) Fertilization by using manure (20 ton/ha), lime (2 ton/ha) and urea (200 kg/ha)

The first step was taking soil samples (composite) prior to study for analysis in the laboratory. It was analysed moisture content, $\mathrm{pH}, \mathrm{C}$ organic, $\mathrm{N}$ total, $\mathrm{P}$ total, $\mathrm{K}$ total, $\mathrm{Fe}$ and $\mathrm{Mn}$. In the end of research (after second season), soil was taken in the each plot to be analysed in the laboratory. The samples were subjected to analysis for $\mathrm{pH}$ and $\mathrm{Fe}$ content for each treatment. All chemical analysis were done in Assessment Institute of Agricultural Technologi (AIAT) East Kalimantan Laboratory.

Herbicide spraying was done before planting. While liming was applied in the determined plots in two weeks after herbicide spraying. Liming was based on soil $\mathrm{pH}$. The soil $\mathrm{pH}$ in the research area was 5.2, therefore lime application as many as 2 ton per ha or $20 \mathrm{~kg}$ per $100 \mathrm{~m}^{2}$. Each plot trial had an area of $100 \mathrm{~m}^{2}$. The ratio between grass and legumes planting was $1: 1$ or $50 \mathrm{~m}^{2}$ for grass and $50 \mathrm{~m}^{2}$ for legumes in each plot. Both were separated in the same plot. Manure was also applied in the determined plots. Manure was from cattle dung. Each plot needed $200 \mathrm{~kg}$. Manure was applied before planting.

Brachiaria humidicola was from the same location. Before planting, grass was cut into pols. The planting space of grass was $40 \times 40 \mathrm{~cm}$. Furthermore, leguminous planting was done with planting space of $40 \times 40 \mathrm{~cm}$. Its planting was done by drilling. Every hole planting was filled with three seeds. 
Data observed was agronomy data namely plant height in two seasons and first harvest data. The first harvest was done in the 60 days. Plant production was the total weight of legume and grass. Statistical analysis was performed using SAS portable 9.0. ANOVA was carried out to compare the difference of means. If there was a significant result, it was followed by Duncan test.

\section{RESULTS AND DISCUSSION}

\section{Soil analysis}

Ex coal mining needs a serious handling and special treatment as an effort to improve its productivity. This research area is a reclamated area for more than 8 years. The result of soil analysis prior to study can be seen in Table 1. which is shown that all critera were not good. This soil was unfertile because of the absence of closure topsoil which is normally fertile. In addition, this layer losted due to mining process (Budianta et al. 2013). The low of $\mathrm{pH}, \mathrm{C}$ organic and $\mathrm{N}$ total showed the low of fertility. $\mathrm{pH}$ solution effect to dissolved metal element. The increase of $\mathrm{pH}$ causes precipitation of heavy metal. Heavy metals such as $\mathrm{Fe}, \mathrm{Cu}$, and $\mathrm{Zn}$ are micro essential element which are needed by plants, but in large quantity will be poisoning (Notohadiprawiro 2006).

Table 1. Soil characteristic prior to research in the ex coal mining in Petangis Village, Batu Engau District, Paser Regency, East Kalimantan 2011

\begin{tabular}{lcc}
\hline \hline Test criteria & Content (before treatment) & Information \\
\hline Moisture content & $9.48(\%)$ & - \\
$\mathrm{pH}$ & 5.21 & Acid \\
$\mathrm{C}$ organic & $0.42(\%)$ & Very low \\
$\mathrm{N}$ total & $0.01(\%)$ & Very low \\
$\mathrm{P}$ total & $49.69 \mathrm{mg} / 100 \mathrm{~g}$ & High \\
$\mathrm{K}$ total & $38.86 \mathrm{mg} / 100 \mathrm{~g}$ & Very high \\
$\mathrm{Fe}$ & $27,719.83 \mathrm{ppm}$ & Very high \\
$\mathrm{Mn}$ & $251.36 \mathrm{ppm}$ & normal \\
\hline
\end{tabular}

Table 1 shows that $\mathrm{P}$ total and $\mathrm{K}$ total were very high. This is likely due to the soil constituent was phosphat rock. Besides, the ex coal mining was polluted by very high Fe, whereas Mn content was still in the normal range. Wang (1995) stated that normal level of Mn content in soil is $170-1,200 \mathrm{mg} / \mathrm{kg}$. The presence of very high heavy metal is predicted to result in inhibition of plant growth.

Table 2 shows that there is no significant result among treatments in term of $\mathrm{pH}$ and $\mathrm{Fe}$ content. However, it can be seen that the Fe content of soil after treatment increased compared with the Fe content prior to research. This is likely due to the water to irrigated the trial plots contain very high Fe. The Fe content of water in ex coal mining in East kalimantan was very high (Marganingrum \& Noviardi 2010).

\section{Forage production}

Forage production differed significantly among treatments and there was an interaction between factor 1 and factor 2 (Table 3) The highest production reached in the treatment of manure + urea in combination between Brachiaria humidicola + Centrosema 
pubescens. This greatest result was due to the high use of manure. Pedrol et al. (2010) stated that the use of manure as many as $20.000 \mathrm{~kg}$ per ha or 20 ton per ha in ex coal mining could increase crop production by 2.2 times. While the use of NPK as many as 200 $\mathrm{kg}$ per ha are able to increase plant production by seven times.

Table 2. $\mathrm{pH}$ and $\mathrm{Fe}(\mathrm{ppm})$ content of soil after treatment

\begin{tabular}{|c|c|c|c|c|c|c|c|c|c|c|}
\hline \multirow{3}{*}{ Treatment } & \multicolumn{10}{|c|}{ Fertilization } \\
\hline & \multicolumn{2}{|c|}{ Control } & \multicolumn{2}{|c|}{ Manure } & \multicolumn{2}{|c|}{$\begin{array}{l}\text { Manure } \\
+ \text { lime }\end{array}$} & \multicolumn{2}{|c|}{$\begin{array}{l}\text { Manure } \\
\text { + urea }\end{array}$} & \multicolumn{2}{|c|}{$\begin{array}{c}\text { Manure + lime } \\
+ \text { urea }\end{array}$} \\
\hline & $\mathrm{pH}$ & $\mathrm{Fe}$ & $\mathrm{pH}$ & $\mathrm{Fe}$ & $\mathrm{pH}$ & $\mathrm{Fe}$ & $\mathrm{pH}$ & $\mathrm{Fe}$ & $\mathrm{pH}$ & $\mathrm{Fe}$ \\
\hline $\begin{array}{l}\text { B. humidicola }+ \\
\text { C. pubescens }\end{array}$ & 4.77 & 36,589 & 4.94 & 44,113 & 5.26 & 36,948 & 4.93 & 30,981 & 5.48 & 34,608 \\
\hline $\begin{array}{l}\text { B. humidicola }+ \\
\text { S. guyanensis }\end{array}$ & 4.93 & 45,003 & 4.93 & 31,862 & 4.89 & 35,790 & 5.20 & 33,657 & 4.89 & 39,561 \\
\hline
\end{tabular}

Table 3. Crop production $(\mathrm{kg})$ per $100 \mathrm{~m}^{2}$ in ex coal mining in Petangis village, Batu Engau Sub district, Paser Regency, East Kalimantan, 2011

\begin{tabular}{|c|c|c|c|c|c|}
\hline \multirow[b]{2}{*}{ Treatment } & \multicolumn{5}{|c|}{ Fertilization } \\
\hline & Control & Manure & Manure + lime & Manure + urea & $\begin{array}{c}\text { Manure + urea }+ \\
\text { lime }\end{array}$ \\
\hline $\begin{array}{l}\text { B. humidicola }+ \\
\text { C. pubescens }\end{array}$ & $8.00^{\mathrm{d}}$ & $21.50^{\mathrm{bc}}$ & $11.25^{\mathrm{d}}$ & $77^{a}$ & $25.75^{\mathrm{b}}$ \\
\hline $\begin{array}{l}\text { B. humidicola }+ \\
\text { S. guyanensis }\end{array}$ & $15.50^{\mathrm{cd}}$ & $12.25^{\mathrm{cd}}$ & $12.04^{\mathrm{cd}}$ & $15^{\mathrm{cd}}$ & $25.03^{\mathrm{b}}$ \\
\hline
\end{tabular}

Different notations differ significantly $(\mathrm{P}<0.001)$

The highest crop production was in the treatment manure + urea and forage combination of $B$. humidicola $+C$. pubescens. It is because nutrient should be available in sufficient quantity and balanced. Therefore, fertilizers are made to meet the requirement of the need. Manure that is a kind of organic fertilizer has many advantages for plant. Manure enhances soil structure that increase root growth. Manure increases organic matter content of the soil. Therefore it improves nutrient exchange capacity, soil water retention, and buffering the soil against alkalinity, acidity, pesticides, salinity and heavy metal (Chen 2006). In addition, urea plays an important role in crop production. In the soil, urea is hydrolized and release ammonium ion. In aerated soil, bacterias change ammonium ion to nitrate. Nitrate is the dominant form in plant nutrition. It is absorbed first into the free space of roots (cell wall spaces) and then across membranes into the plant cell themselves (Novoa \& Loomis 1981).

Moreover, Subowo (2010) stated that in the first step of open pit mining can be developed for fast growing cover crop such as Calopogonium sp, Pueraria sp, Centrosema sp. Budianta et al. (2013) reported that the use of fast growing leguminous are able to improve the soil fast. Furthermore, crop legumes planting as pioneer plants are needed because ground capacity is relatively weak. Crop legumes have capability to utilize air nitrogen as the result of symbiosis between rhizobium bacteria and organic compound rich in nitrogen. Nitrogen is a macro essential nutrient for plant and the main limiting factor on the opening grounds in tropics. With this condition, it will recover soil fertility quickly. 


\section{CONCLUSION}

The improvement of forage in ex coal mining can be done by right forage planting and fertilizing. Fertilization by using manure 20 ton per hectare and urea $200 \mathrm{~kg}$ per hectare combined with $B$. humidicola $+C$. pubescens had a significant result $(\mathrm{P}<0.01)$. The crop production with this treatment result in 9.6 times than control.

\section{REFERENCES}

BPMD. 2012. Penyusunan kajian investasi di lahan eks tambang. Samarinda (Indonesia): Badan Perijinan dan Penanaman Modal Daerah Kalimantan Timur.

BPS. 2013. Kalimantan Timur dalam angka. Samarinda (Indonesia): Badan Pusat Statistik Kalimantan Timur.

Budianta D, Gofar N, Andika, GA. 2013. Improvement of sand tailing fertility derived from post tin mining using leguminous crop applied by compost and mineral soil. J Trop Soil. 8:217223.

Chen JH. 2006. The combined used of chemical and organic fertilizers and/or biofertilizer for crop growth and soil fertility. In: International Workshop on Sustained Management of the Soil Rhizosphere System for Efficient Crop Production and Fertilizer Use. Bangkok (Thailand): Land Development Department.

Lavelle P, Bignell D, Lepage M, 1997. Soil function in changing world: The role of intervetebrate ecosystem engineer. Eur J Soil Biol. 17:258-269.

Marganingrum D, Noviardi R. 2010. Pencemaran air dan tanah di kawasan pertambangan batubara di PT Berau Coal, Kalimantan Timur. Riset Geologi dan Pertambangan 20:11-20.

Novoa R, Loomis RS. 1981. Nitrogen and plant production. Plant Soil 58:177 204.

Notohadiprawiro. 2006. Logam berat dalam pertanian. Repro: Ilmu tanah. Yogyakarta (Indonesia): Universitas Gadjah Mada.

Pedrol N, Puig CG, Souza P, Forjan R, Vega FA, Asensio V, Gonzales L, Cerqueira B, Covelo, EF, Andrade L. 2010. Soil fertility and spontaneous revegetation in lignite spoil banks under different amendments. Soil Tillage Res. 110:134-142.

Rattan RK, Datta SP, Chhonkar PK, Suribabu K, Singh AK. 2005. Long-term impact of irrigation with sewage effluents on heavy metal content in soils, crops and groundwater - A case study. Agric Ecosyst Env. 109:310-322.

Subowo G. 2010. Penambangan sistem terbuka ramah lingkungan dan upaya reklamasi pascatambang untuk memperbaiki kualitas sumberdaya lahan dan hayati tanah. J Sumber Daya Lahan. 5:83-94.

Verhagen R, Klooker J, Bakker JP. 2001. Restoration success of low production plant communities on former agricultural soils after top soil removal. Appl Veg Sci. 4:75-82.

Wang JG. 1995. Soil chemistry of plant nutrients. Beijing (China): China Agricultural University Press.

Yustika RD, Talaohu SH. 2006. Bisakah lahan bekas tambang batubara untuk pengembangan pertanian. Warta Penelitian dan Pengembangan Pertanian. 28:8-10. 